\title{
ANALISIS KOMPETENSI GURU TERHADAP MOTIVASI BELAJAR PADA MATA PELAJARAN ILMU PENGETAHUAN SOSIAL DI KELAS III SDN 3 CILEUYA
}

\author{
Sela Sri Noviati ${ }^{1}$, Agus Saeful Anwar ${ }^{2}$ \\ STKIP Muhammadiyah Kuningan ${ }^{1}$, STKIP Muhammadiyah Kuningan ${ }^{2}$. \\ Email: saefulanwar@upmk.ac.id
}

\section{Info Artikel}

\section{Sejarah Artikel:}

Diterima Bulan x, 202x

Dipublikasikan Bulan x, 202x

Keywords: kompetensi

Guru,Motivasi

Belajar, IPS

\section{Abstrak}

Analisis Kompetensi Guru terhadap Motivasi Belajar pada Mata Pelajaran IPS di Kelas III SDN 3 Cileuya. Tujuan penelitian ini adalah untuk mengetahui kompetensi guru dan motivasi belajar pada mata pelajaran IPS di SDN 3 Cileuya. Metode penelitian menggunakan metode kualitatif penelitian ini akan mengahasilkan deskripsi dan analisis yang berkaitan dengan kompetensi guru dan motivasi belajar pada mata pelajaran IPS kelas III SDN 3 Cileuya. Lokasi penelitian bertempat di SD Negeri 3 Cileuya dengan subjek penelitian yaitu siswa kelas III guru beserta kepala sekolah sebagai informan. Teknik pengumpulan data dan instrumen adalah angket, wawancara, observasi dan dokumentasi. Data dianalisis dengan menggunakan cara pengumpulan data, reduksi data, penyajian data, penarikan kesimpulan. Hasil penelitian angket menunjukan 83\% kompetensi pedagogik guru sudah dimiliki 75\% kompetensi kepribadian yang dimiliki oleh guru kelas III $77 \%$ kompetensi sosial yang dimiliki guru kelas III dan 78\% kompetensi professional yang dimiliki oleh guru kelas III. Dalam mengajar mata pelajaran IPS menunjukan hasil angket yang diperoleh adalah 79\% kategori kompetensi yang dimiliki guru menunjukan bahwa guru kelas III dalam mengajar sudah baik.

\section{Abstract}

Teacher Competency Analysis of Learning Motivation Social Sciences Subjects in Class III SDN 3 Cileuya. The purpose of this study was to determine teacher competence and learning motivation in Social Studies subjects at SDN 3 Cileuya. The research method using qualitative research method will produce a description and analysis relating to teacher competence learning motivation in social studies subjects III class 3 Cileuya. The location of the study was at SDN 3 Cileuya with the research subjects being students of class III teacher and school principals as infirmants. Data collection techniques and instruments are questionnaire, interview, observation, and documentation. Data were analyzed using data collection, data reduction, data presentation, drawing conclusions. The results of research on the net show that $83 \%$ of teacher pedagogical competencies are already owned by $75 \%$ of personality competencies owned by class III teacher 77\% of social competencies owned by class III teacher and $78 \%$ professional competencies owned by class III teacher. In teaching social studies subjects showed that the questionnaire results obtained were $79 \%$ of the competency categories owned by the teacher indicating that the third grade teachers in teaching were already good.
Alamat Korespondensi Email
: STKIP Muhammadiyah
: saefulanwar@upmk.ac.id

(C) 2020 Sela Sri Novianti ${ }^{1}$, Agus saeful Anwar ${ }^{2}$. Under the license CC BY-SA 4.0 


\section{Jurnal Lensa Pendas, Vol. 5 Nomor 1 , 2020, HIm 1-6}

Sela Sri Novianti ${ }^{1}$, Agus Saeful Anwar ${ }^{2}$.,

\section{PENDAHULUAN}

Pendidikan merupakan hal yang penting bagi setiap manusia, pendidikan berlangsung terus menerus, artinya berlangsung sepanjang hayat (long life education). Pendidikan harus terus direformasi sepanjang zaman, karena perkembangan ilmu pengetahuan dan teknologi tidak bisa dibendung terus melaju dan memengaruhi pola kehidupan masyarakat. Pendidikan berlangsung dalam konteks hubungan individu yang bersifat multidimensi, baik dalam hubungan individu dengan Tuhannya, sesama manusia, alam bahkan dengan dirinya sendiri. Dengan pendidikan juga dapat mengembangkan potensi, membentuk karakter, membangun kreativitas dan mengabdi kepada masyarakat.

Menurut W.J.S. Poerwadiminta menjelasakan secara linguistis, sebagai kata benda, pendidikan berarti proses perubahan sikap dan tingkah laku seseorang atau kelompok orang dalam usaha mendewasakan manusia melalui upaya pengajaran dan latihan.

Menurut Tedi Priatna pendidikan merupakan usaha pengembangan kualitas diri manusia dalam segala aspeknya. Pendidikan sebagai aktivitas yang disengaja untuk mencapai tujuan tertentu dan melibatkan berbagai faktor yang saling berkaitan antara satu dengan yang lainnya, sehingga membentuk satu sistem yang saling memengaruhi.

Menurut Ahmad D Marimba pendidikan adalah bimbingan jasmani dan rohani untuk membentuk kepribadian utama, membimbing kepribadian jasmniah dan rohaniah sebagai perilaku konkret yang memberikan manfaat pada kehidupan siswa di masyarakat.

Pada dasarnya pembelajaran IPS dibutuhkan peran guru yang sangat baik agar siswa tertarik dalam mengikuti pembelajaran. Untuk itu guru harus memiliki kompetensi agar kualitas pemebelajaran menjadi lebih baik. Di dalam pembelajaran guru harus bisa memotivasi siswa, guru akan menemukan berbagai karakteristik siswa yang berbeda dengan motivasi belajar yang berbeda ada pula.

Berdasarakan permasalahan diatas maka penelitian ini bertujuan untuk mengkaji lebih dalam permasalahan pada mata pelajaran IPS yaitu pembelaajaran sangat membosankan kurang menarik adanya siswa yang memiliki motivasi belajar yang sangat rendah, sedang dan ada juga siswa yang memiliki motivasi belajar yang sangat tinggi, guru pada umumnya melakukan pembelajaran dengan metode ceramah, guru juga sangat terpaku pada buku pelajaran, yang membuat siswa tidak memperhatikan apa yang disampaikan guru, kurangnya penggunaan media sehingga siswa kurang memahami apa yang dijelaskan guru, kurangnya disiplin waktu. Hal ini membuat siswa bosan dan malas karena terus menerus mendengarkan guru yang berbicara di depan. Maka mereka tidak memperhatikan guru saat dan pada akhirnya materi yang disampaikan guru tidak bisa diterima oleh siswa dengan baik. Untuk itu guru harus menggali kompetensinya.

Berdasarkan permasalahan di atas peneliti akan melakukan penelitian dengan judul "Analisis Kompetensi Guru terhadap Motivasi Belajar pada Mata Pelajaran Ilmu Pengetahuan Sosial di Kelas III SDN 3 Cileuya.

\section{METODE PENELITIAN}

Metode yang digunakan dalam penelitian ini adalah metode kualitatif, penelitian ini akan menghasilkan deskripsi dan analisis yang berkaitan dengan Analisis Kompetensi Guru terhadap Motivasi Belajar di kelas III pada Mata Pelajaran Ilmu Pengetahuan Sosial SDN 3 Cileuya. Menurut Sugiyono (2015 : 15) Penelitian kualitatif ini berlandaskan filsafat postpostivisme, yang digunakan untuk meneliti pada kondisi obyek 


\section{Jurnal Lensa Pendas, Vol. 5 Nomor 1, 2020, HIm 1-6}

Sela Sri Novianti ${ }^{1}$, Agus Saeful Anwar ${ }^{2}$.,

yang alamiah.

Penelitian kualitatif ini berdasarkan pada metodologi yang menyelidiki suatu fenomena sosial. Pada penelitian kualitatif ini diambil karena penelitian ini sasaranya adalah obyek yang digali sebanyak mungkin, penelitian kualitatif ini menggumakan metode observasi, angket wawancara dan dokumentasi.

Dalam penelitian kualitatif, data diperoleh dari berbagai sumber, dengan menggunakan teknik pengumpulan data yang bermacam-macam (triangulasi), dan dilakukan secara terus menerus sampai datanya jenuh. Pada proses analisis data dalam penelitian kualitatif dilaksanakan analisis sebelum di lapangan, analisis selama di lapangan.

Pada penelitian ini peneliti menggunakan model Miles and Hubermen analisis data dalam penelitian kualitatif dilakukan pada saat pengumpulan data berlangsung, dan setelah pengumpulan data dalam periode teretntu. Pada saat wawancara, peneliti sudah melakukan analisis terhadap jawaban yang diwawancarai. Miles Hubermen mengemukan bahwa aktivitas dalam analisis data kualitatif dilakukan secar interaktif dan berlangsung secara terus menerus sampai tuntas, sehingga datanya sudah jenuh.

\section{HASIL PENELITIAN DAN PEMBAHASAN}

Bersarkan hasil peneliti, penulis menemukan 3 jurnal yangt terkait dengan Kompetensi Guru di Sekolah Dasar, diantaranya :

Peran Guru Dalam Proses Pembelajaran IPS di Kelas IV SD Gugus Gatotkaca Kecamatan Semarang Barat Kota Semarang oleh Gesit Rahmadhani Wahyu Putri pada Tahun 2016 Fakultas Ilmu Pendidikan Universitas Negeri Semarang dengan hasil penelitian adalah Guru kelas IV telah menjalankan perannya dalam proses pembelajaran memperoleh prsentasi rata-rata $81,17 \%$ dengan kriteria sangat baik. Hambatan pelaksanaan peran guru dalam proses pembelajaran IPS yaitu factor guru adalah masih minimnya pengalaman professional guru dan masa kerja mengajar guru yang belum terlalu lama. Faktor siswa yaitu kemampuan belajar siswa yang rendah dan gaya belajar yang berbeda. Sedengkan dari factor sekolah adalah masih minimnya media pembelajaran sarana dan prasana yang masih minim.

Analisis Kompetensi Guru

Pembelajaran IPS (Ilmu Pengetahuan Sosial) Di SDN Tunggulasari II Surakarta oleh Sahbudin Universitas Muhammadiyah Surakarta dengan hasil Guru harus mengenal secara baik karakteristik siswa serta mampu berbuat adil dan objektif mereka. Guru harus terus meningkatkan kemampuan personal dan sarana prasarana belum memadai sehingga mengalami kesulitan dalam meningkatkan mutu pendidikan.

Peran Kompetensi Profesional Guru dalam Meningkatkan Minat Belajar Siswa pada Mata Pelajaran IPS Terpadu kelas VIII di MTs. Nida'ul Islam Jelateng Lombok Tengah Tahun 2015/2016 Fakultas Ilmu Tarbiyah dan Keguruan (FTIK) Institut Agama Islam Negeri (IAIN) Mataram dengan hasil penelitian Kompetensi Profesional guru dalam meningkatkan minat belajar siswa pada mata pelajaran IPS Terpadu di di MTs. Nida'ul Islam Jelateng memiliki peran yang sangat penting yang direalisasikan berdasarkan kompetensi yang harus dimiliki oleh guru professional diantaranya menguasai bahan pengajaran yang disampaikan, mengelola program pembelajaran, mengelola kelas, menilai prestasi-prestasi siswa, mengenal dan menyelenggarakan administrasi pendidikan, mengenal fungsi program pelayanan bimbingan dan penyuluhan, mengelola interaksi belajar mengajar, dan menggunakan media/sumber belajar.

Penelitian yang akan dilaksanakan berbeda dengan penelitian yang telah dilakukan sebelumnya, peneliti ini akan mencoba meneleiti kompetensi guru dalam meningkatkan motivasi belajar siswa pada mata pelajaran IPS di kelas III.

Kompetensi Guru kelas III di SDN 3 Cileuya. Kompetensi menurut UU No. 13 


\section{Jurnal Lensa Pendas, Vol. 5 Nomor 1, 2020, HIm 1-6}

Sela Sri Novianti ${ }^{1}$, Agus Saeful Anwar ${ }^{2}$.,

tahun 2003 tentang Ketenagakerjaan pasal 1 ayat 10 menyebutkan bahwa "Kompetensi adalah kemampuan kerja setiap individu yang mencakup aspek pengetahuan, keterampilan dan sikap kerja yang sesuai dengan standar yang ditetapkan". Guru harus menguasai kompetensi yang meliputi kompetensi professional, kompetensi pedagogik, kepribadian, dan sosial, karena hal ini saing berkaitan satu sama lain untuk mewujudkan tujuan pendidikan dalam proses pembelajaran.

1. Kompetensi Profesional menurut Depdikbud, (Satori 2008 : 224) mengenai kompetensi professional yaitu penguasaan bahan pelajaran, penggunaan media dan sumber pembelajaran. Berdasarkan analisis dilapangan bahwa kompetensi professional guru cukup baik, guru kelas III sudah menguasai materi pembelajaran yang diajarkan dengan baik selain itu guru kelas III juga mengajar materi dengan jelas sehingga siswa kelas III mudah untuk memahami materi yang diajarkan oleh guru Dalam kegiatan belajar mengajar guru kelas III menggunakan berbagai sumber pembelajaran yang relevan yaitu modul, lks dan sumber belajar lainnya.

2. Kompetensi pedagogik merupakan kemampuan yang berkaitan dengan pemahaman siswa dan pengelolaan pembelajaran yang mendidik dan dialogis. . Menurut Prof. Dr. J. Hoogveld (Saddulloh 2014 : 2) pedagogik adalah ilmu yang mempelajari masalah membimbing anak kearah tujuan tertentu, yaitu supaya ia kelak "mampu secara mandiri menyelesaikan hidupnya". Berdasarkan hasil analisis dilapangan bahwa kompetensi pedagogik memang cukup baik guru kelas III dan hasil angket menunjukan bahwa kompetensi pedagogik guru kelas III prosentasinya menunjukan bahwa $83 \%$ dan kompetensinya sudah sesuai dengan yang telah ditetapkan oleh pemerintah.

3. Kompetensi sosial adalah kemapuan guru untuk memahami dirinya sebagai bagian yang tidak terpisahkan dari masyarakat. Berdasarkan hasil analisis di lapangan bahwa kompetensi sosial guru sudah baik ditambah dengan hasil angket yang peneliti lakukan kompetensi sosial guru kelas III menunjukan $77 \%$ guru kelas III sudah berkomunikasi dengan baik dengan sesama pendidik tenaga kependidikan orangtua siswa serta masayarakat sekitar, komunikasi adalah hal yang penting dalam proses pembelajaran. Kepala sekolah juga menjelaskan tentang kompetensi sosial guru beliau mengatakan bahwa: "Kompetensi sosial guru kelas III sudah terjalin dengan baik antara kepala sekolah, sesama pendidik, tenaga kependidikan, orang tua siswa dan masyarakat"

4. Kompetensi Kepribadian adalah kompetensi yang berkaitan dengan perilaku pribadi guru itu sendiri yang kelak harus memiliki nilai-nilai luhur, sehingga terpancar dalam perilaku sehari-hari. Kunandar (Novauli 2015 : 50) menyatakan bahwa "Kompetensi kepribadian yaitu perangkat prilaku yang berkaitan dengan kemampuan individu dalam mewujudkan dirinya sebagai pribadi yang mandiri untuk melakukan transformasi diri, identitas diri, dan pemahaman diri". Berdasarkan analisis yang dilakukan guru mempunyai kepribadian yang berahlak mulia serta menjadi teladan bagi siswa dan masyarakat, guru kelas III menampilkan pribadi yang menarik sehingga siswa senang dengan guru pada saat pembelajaran. Sejalan dengan pendapat dari kepala sekolah yang mengatakan bahwa: "Kompetensi kepribadian guru kelas III sudah sesuai dengan kompetensi yang ditetapkan pemerintah. Seorang guru harus memiliki kepribadian yang baik untuk ditiru oleh para siswanya dapat membimbing siswanya. Dalam hal ini guru juga mengembangkan kepribadiannya agar menjadi pribadi yang lebih baik."

Dari pernyataan diatas dapat disimpulkan bahwa kompetensi kepribadian guru kelas III baik ditambah dengan hasil angket yang peneliti lakukan bahwa kepribadian guru kelas III menunjukan prosentasi $75 \%$ memiliki kepribadian untuk ditiru oleh siswa dan masyarakat sekitar baik dilingkungan sekolah maupun lingkungan luar sekolah.

Motivasi Belajar Siswa Kelas III

Menurut Sudarwan (Siti Suprihatin 2015 : 1) motivasi diartikan sebagai kekuatan, dorongan, kebutuhan, semangat, tekanan, atau mekanisme psikologis yang mendorong seseorang 


\section{Jurnal Lensa Pendas, Vol. 5 Nomor 1, 2020, HIm 1-6}

Sela Sri Novianti ${ }^{1}$, Agus Saeful Anwar ${ }^{2}$.,

atau sekelompok orang untuk mencapai prestasi tertentu sesuai dengan apa yang dikehendakinya.

Menurut Mc. Donald (Djamarah 2012 : 34) motivasi adalah perubahan energy dalam diri seseorang yang ditandai dengan munculnya felling dan didahului dengan tanggapan terhadap adanya tujuan.

Berdasarkan analisis yang didapat oleh peneliti bahwa motivasi belajar siswa cukup baik siswa kelas III menyukai mata pelajaran IPS yang diajarakan oleh guru karena mata pelajaran IPS mudah dipahami oleh siswa, tetapi beberapa siswa yang tidak suka dengan mata pelajaran IPS dikarenakan beberapa faktor,hasil wawancara dengan guru bahwa motivasi belajar siswa bervariasi ada bervariasi ada yang tinggi dan ada juga yang rendah.

\section{Guru \\ Triangulasi Sumber Data Aktivitas}

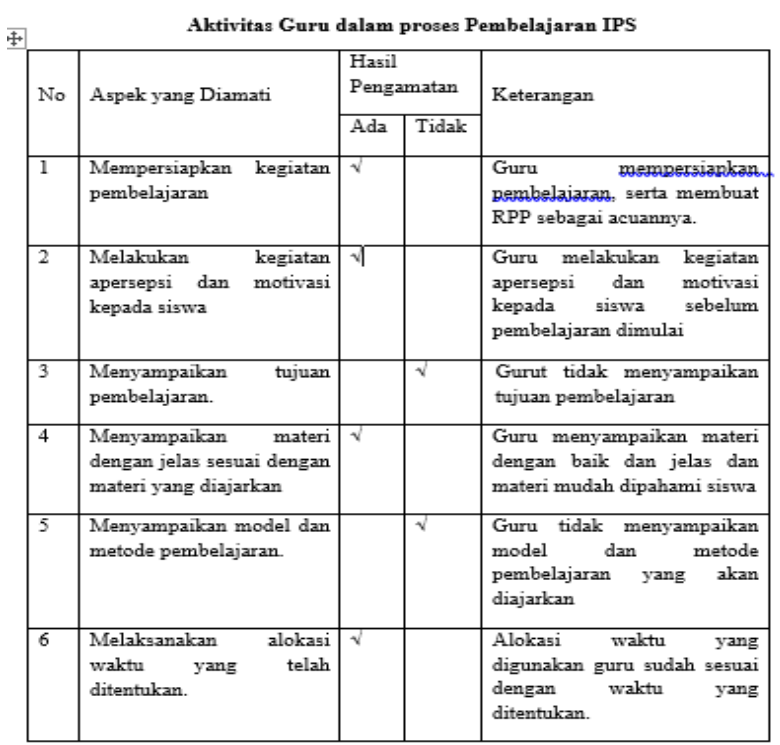

Pada tanggal 13 Mei 2019 peneliti ikut dalam kegiatan pembelajaran untuk mulai melakukan observasi serta mengamati aktivitas guru di dalam kelas, aktivitas siswa dan untuk mengetahui motivasi belajar siswa selain mengamati guru yang sedang mengajar peneliti juga menggunakan angket untuk mengetahui minat belajar siswa pada mata pelajaran IPS. Dalam kegiatan belajar mengajar pada mata pelajaran IPS guru menjelaskan materi dengan jelas dan sesuai dengan materi yang diajarkan, selain itu materi yang diajarakan oleh guru mudah dipahami oleh siswa.
Pada saat kegiatan pembelajaran dimulai guru selalu mempersiapkannya pembelajaran dengan baik serta dengan adanya RPP guru mengacu pada RPP yang telah dibuatnya. Kebetulan pada saat peneliti melakukan observasi guru menjelaskan mengenai materi pasar modern dan pasar tradisional, siswa memperhatikan guru pada saat mengajar mata pelajaran IPS sepertinya siswa kelas III sdn 3 Cileuya sangat senang dengan materi yang diajarkan oleh guru walaupun ada beberapa siswa yang tidak memperhatikan guru pada saat mengajar di kelas.

Setelah menjelaskan materi guru memberikan tugas dalam mata pelajaran IPS untuk didiskusikan bersama-sama dan membentuk beberapa kelompok untuk mendiskusikan tentang materi yng telah diajarakan oleh guru pada mata pelajaran IPS, setelah berdiskusi guru memberikan pertanyaan kepada siswa mengenai materi yang sudah didiskusikan siswa bersama-sama. Peneliti mengamati aktivitas guru dalam mengajar di dalam kelas. adapun hasil observasi yang dilakukan oleh guru dalam mata pelajaran IPS di kelas III.

\section{Triangulasi Deskripsi Angket Siswa}

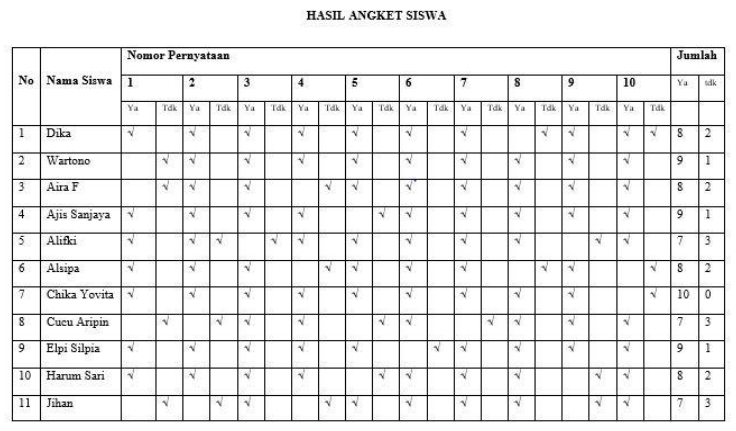

Berdasarakan hasil angket yang diberikan kepada siswa menunjukan bahwa motivasi belajar siswa pada mata pelajaran IPS cukup baik $78 \%$ siswa menyukai mata pelajaran IPS karena mata pelajaran IPS mudah dipahami oleh siswa. Hal ini dikarenakan beberapa faktor diantaranya kompetensi pedagogik guru yang baik dan mampu memahami karakteristik siswa ditambah dengan kepribadian guru yang sangat baik sehingga anak menyukai guru ketika guru menyampaikan pembelajaran IPS di kelas serta penampilan guru pada saat pembelajaran menarik guru juga dituntut untuk memiliki jiwa sosial yang tinggi guru juga harus dapat 


\section{Jurnal Lensa Pendas, Vol. 5 Nomor 1 , 2020, HIm 1-6}

Sela Sri Novianti ${ }^{1}$, Agus Saeful Anwar ${ }^{2}$.,

berkomunikasi dengan sesama pendidik, tenaga kependidikan, orangtua serta harus pandai bergaul dengan masyarakat. kompetensi professional merupakan penguasaan guru dalam membimbing dan mendidik siswa.

Dari hasil observasi yang dilakukan oleh peneliti mengenai aktivitas guru pada saat proses pembelajaran berlangsung menunjukan bahwa materi yang diajarkan oleh guru mudah dipahami oleh siswa, guru mengajar mata pelajaran IPS dengan jelas sehingga para siswa menyukai mata pelajaran IPS serta membuat siswa semangat dalam belajar IPS.

\section{SIMPULAN}

Berdasarkan hasil penelitian diatas dapat disimpulkan guru kelas III sudah memiliki keempat kompetensi yang telah ditetapkan oleh pemerintah. Berdasarkan hasil angket bahwa kompetensi guru kelas III cukup baik. Hasil penelitian angket menunjukan $83 \%$ kompetensi pedagogik guru sudah dimiliki $75 \%$ kompetensi kepribadian yang dimiliki oleh guru kelas III $77 \%$ kompetensi sosial yang dimiliki guru kelas III dan $78 \%$ kompetensi professional yang dimiliki oleh guru kelas III. Dalam mengajar mata pelajaran IPS menunjukan hasil angket dapat disimpulkan bahwa prosentasi guru mengajar pada mata pelajaran IPS diperoleh angka mencapai $79 \%$ kompetensi yang dimiliki oleh guru kelas III dan guru kelas III sudah memiliki keempat kompetensi yang ditetapkan oleh pemerintah, serta dalam mengajar mata pelajaran IPS guru kelas III sudah cukup baik.

Motivasi belajar siswa dalam pembelajaran IPS dikategorikan baik hasil angket menunjukan bahwa $78 \%$ siswa menyukai mata pelajaran IPS dan ketika guru menyampaikan materi pembelajaran materi tersebut mudah dipahami oleh siswa. Tetapi ada beberapa siswa yang tidak suka dengan mata pelajaran IPS dikarenakan beberapa faktor. Hasil wawancara dengan guru menunjukan bahwa motivasi belajar siswa berbeda ada yang memiliki motivasi belajar tinggi adapula motivasi belajar rendah

\section{DAFTAR PUSTAKA}

Djamarah, Bahari.2012. Prestasi Belajar dan Kompetensi Guru. Surabaya-Indonesia: Usaha Nasional.

Ischak, 2007. Pendidikan IPS di SD. Jakarta: Universitas Terbuka.

Novauli Feralys, 2015. Kompetensi Guru dalam Peningkatan Prestasi Belajar: Universitas Syiah Kuala.

Sadulloh, Uyoh dkk. 2014. Pedagogik (Ilmu Mendidik). Bandung: Alfabeta cv.

Satori, Djam'an dkk. 2008. Profesi Keguruan. Jakarta: Universitas Terbuka.

Sugiyono, 2015. Metode Penelitian Pendidikan (Penelitian Kuantitatif, Kualitatif dan $R$ \& D). Bandung: Alfabeta cv.

Suprihatin Siti, 2015. Upaya Guru Dalam Meningkatkan Motivasi Belajar Siswa: Pendidikan Ekonomi FKIP Universitas Muhammadiyah Metro. 